\title{
Comparison of trauma scores for predicting mortality and morbidity on trauma patients
}

\author{
Reyhan Orhon, M.D., ${ }^{1}$ Şevki Hakan Eren, M.D., ${ }^{2}$ Şule Karadayı, M.D., ${ }^{2}$ İlhan Korkmaz, M.D., ${ }^{2}$ \\ Abuzer Coşkun, M.D., ${ }^{2}$ Mehmet Eren, M.D., ${ }^{3}$ Nurkay Katrancıoğlu, M.D. ${ }^{4}$
}

\author{
${ }^{1}$ Department of Emergency Medicine, Gaziantep State Hospital; Gaziantep; \\ ${ }^{2}$ Department of Emergency Medicine, Cumhuriyet University Hospital, Sivas; \\ ${ }^{3}$ Department of Orthopaedics and Traumatology, Ankara Yenimahalle State Hospital, Ankara; \\ ${ }^{4}$ Department of Cardiovascular Surgery Service, Cumhuriyet University Hospital, Sivas
}

\begin{abstract}
BACKGROUND: In this study, we compared the anatomical, and physiological scoring systems trauma revised injury severity score (TRISS), revised trauma score (RTS), injury severity score (ISS), new injury severity score (NISS) to each other, to find out the most accurate and reliable trauma score for the risk classification of morbidity and mortality among the trauma patients.

METHODS: This is a cross-sectional study, which included 633 patients who admitted to our University Hospital Emergency Department during an 8-month period due to trauma. All blunt and penetrating traumas (traffic accident, assault, etc.) patients above 16 years were included.

RESULTS: Arrival time trauma scores (ISS, NISS, RTS, and TRISS) of the patients was calculated. Mean trauma score for the mortality prediction was calculated, and the $p$ value was equal for all $(p=0.00 \mathrm{I})$. Trauma scores were also analyzed for the hospitalization time in intensive care unit (ICU). While NISS, RTS, and TRISS values were significant $(p=0.048, p=0.048$, and $p=0.017$, respectively), ISS value was not significant $(p=0.257)$ for predicting the ICU hospitalization time. Only TRISS was a good predictor for the mechanically ventilation time in ICU patients $(\mathrm{p}=0.0 \mathrm{I})$.
\end{abstract}

CONCLUSION: In conclusion, we determined that the anatomical trauma scores (NISS, ISS) predicted the hospitalization and ICU necessities better, whereas TRISS, an anatomo-physiological trauma score, defined the ICU hospitalization and mechanically ventilation time better.

Key words: Morbidity; mortality; trauma; trauma score.

\section{INTRODUCTION}

Trauma is a heterogeneous disease that affects all age groups with violence more or less. It takes the first place between I and 35 age group patients. In 1989, 160,000 people died as a result of trauma in the United States and this number is approximately four times that of those who died from acquired immunodeficiency syndrome in the same year. ${ }^{[1]}$ According

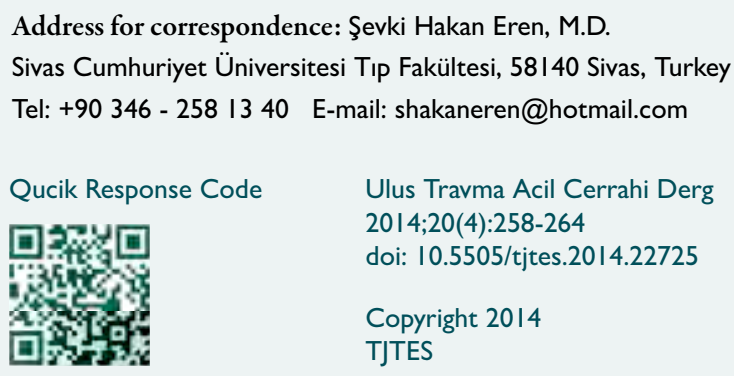

to the Turkey Statistics Institute data 3\% of all deaths in our country were due to trauma, and the most common cause of trauma deaths were motor vehicle accidents, 1516 deaths. Twenty-six percent of these deaths were between 20 and 35 ages and $74 \%$ were male. ${ }^{[2]}$

Scoring systems are cornerstones of the trauma epidemiology. Graded according to the severity of injury is necessary for the management of trauma and as well as a basic requirement for clinical trials. ${ }^{[3]}$ Trauma revised injury severity score (TRISS) and injury severity score (ISS), are widely used in the estimation of mortality due to injury. ${ }^{[4,5]}$

In many countries, some trauma scores were developed, and continue to be developed, for the peoples exposed to assess the severity of trauma and the resulting damage. Measurable and comparable objective criteria are required for determining the severity of trauma. For this purpose, many anatomical and physiological scoring systems are created. ${ }^{[6-8]}$ 
These scoring systems can provide some benefits: (I) objectively determine the level of the injuries, which enables the care units to classify the patient's centers according to the specified special care they need. (2) The physiological data that are associated with mortality in the early period after an injury can be determined to follow-up the at-risk patients. (3) The scores can be helpful by transporting the patients to the appropriate hospitals. (4) Patients who may benefit the most from treatment may be primarily determined. (5) They can enable to determine the kind of health institutions, which are necessary in this region. (6) Epidemiological databases about the injuries and its severities can be created. (7) According the results obtained in the treatment of trauma patients, the effectiveness of health institutions can be compared. ${ }^{[6,9,10]}$ Thus, can increase the management quality of trauma cases. The scoring systems which are compared are as follows:

A. Anatomical scoring systems

- Abbreviated injury scale (AIS)

- ISS

- New injury severity score (NISS)

B. Physiological scoring systems

- Glasgow coma scale (GCS)

- Revised trauma score (RTS)

C. Combined scoring system

- TRISS

\section{MATERIALS AND METHODS}

This is a cross-sectional study, included 633 trauma patients who admitted Hospital Emergency Department between November 2009 and July 2010. The ethical approval number was taken from the Local Ethics Committee.

This is a descriptive study with cross-sectional properties. The arrival time trauma scores (ISS, NISS, RTS, and TRISS) were calculated both blunt and penetrating trauma patients who were over 16-year-old. The trauma scores were calculated according to their physiological and anatomical criteria such as age, injury mechanism, GCS, pulse rate, blood pressure, respiratory rate, type and degree of the internal and external organ lesions.

The inpatients were followed-up for their hospitalization, intensive care unit (ICU), and mechanical ventilation time and mortality rates. Trauma scores were also calculated for those who were treated as outpatients. On the basis of these results, we determined to find out the trauma scoring system, which can predict best the mortality rate, hospitalization indications, hospitalization duration, ICU and mechanical ventilation requirements, length of stay in intensive care and mechanical ventilation.

The patients under 16 years, burns, pathologic fractures and the ones who died in the emergency department were excluded from the study. Statistical Package for Social Sciences 14.0 was used for analyses. Chi-square, the significance test for the difference between two means, Man-Whitney U-test and correlation analysis were performed. Our data are shown in tables as mean \pm standard deviation and $p<0.05$ was accepted as significant.

\section{RESULTS}

The mean age values of 633 individuals were $39.65 \pm 17.07$ (16-87) years. $482(\% 76.1)$ patients were male and 151 (23.9\%) female, 53I (83.8\%) cases had blunt trauma, whereas 102 (16.1\%) suffered from penetrating trauma. Eight patients (1.3\%) could not survive. The treatment of the 378 (\%59.7) patients was made in hospital, whereas 255 (\%40.3) patients were discharged after their first treatment in the emergency department. Thirty-eight inpatients were directed to ICU and 20 patients needed mechanical ventilation.

The trauma scores for all individuals are shown in Table I. The minimum score for all trauma scores was 0.0 point; the maximum scores were 4I.0, 48.0, 7.84, and 99.7 points for ISS, NISS, RTS, and TRISS, respectively.

All mean trauma scores of the death patients were significantly higher than survived patients $(p=0.00 \mathrm{I})$. Accordingly, all trauma scores were equal for predicting the mortality (Table 2).

The trauma scores of the discharged and hospitalized patients were calculated and compared. While trauma scores of ISS and NISS were higher among hospitalized patients, RTS and TRISS were higher in patients who were discharged from the emergency department. The difference was statistically significant for all trauma scores $(p<0.05$, Table 3$)$. However,

Table I. Trauma scores for all patients

\begin{tabular}{lcccc}
\hline & $\mathbf{n}$ & Minimum & Maximum & Mean \pm SD \\
\hline Injury severity score & 633 & 0.00 & 41.00 & $6.02 \pm 7.11$ \\
New injury severity score & 633 & 0.00 & 48.00 & $7.18 \pm 8.51$ \\
Revised trauma score & 633 & 0.00 & 7.84 & $7.73 \pm 0.54$ \\
Trauma revised injury severity score & 633 & 0.00 & 99.7 & $98.02 \pm 7.42$ \\
\hline SD. Standard deviation & & & &
\end{tabular}

SD: Standard deviation. 
Table 2. Mean trauma score for the patients who died and survived

\begin{tabular}{|c|c|c|c|c|c|}
\hline \multirow[t]{2}{*}{ Trauma scores } & \multirow[t]{2}{*}{$\mathbf{n}$} & Ex & \multirow[t]{2}{*}{$\mathbf{n}$} & Living patients & \multirow[t]{2}{*}{$\mathbf{p}$} \\
\hline & & Mean \pm SD & & Mean $\pm S D$ & \\
\hline Injury severity score & 8 & $24.37 \pm 12.85$ & 625 & $5.78 \pm 6.71$ & $=0.001$ \\
\hline New injury severity score & 8 & $27.62 \pm 12.85$ & 625 & $6.92 \pm 8.13$ & $=0.001$ \\
\hline Trauma revised injury severity score & 8 & $72.80 \pm 19.35$ & 625 & $98.34 \pm 6.58$ & $=0.001$ \\
\hline Revised trauma score & 8 & $5.62 \pm \mid .31$ & 625 & $7.75 \pm 0.46$ & $=0.00 \mathrm{I}$ \\
\hline
\end{tabular}

SD: Standard deviation

according to the t-test statistic values the prediction score rate for hospitalization is defined better by anatomical scoring systems (NISS, ISS) then physiological or combined scoring systems (TRISS, RTS).

The hospitalization time has a positive correlation with ISS $(r=0.36)$ and NISS $(r=0.42)$. Whereas RTS and TRISS have a negative correlation $(r=-0.2$ and $r=-0.14)$ with the hospitalization time.

In spite of the fact that the $p$ values were statistically significant, the correlation coefficient was weak in all trauma scores for hospitalization time (Table 4).

From the 378 hospitalized patients, 38 hospitalized in the
ICU. The service and ICU mean trauma scores were compared. The mean values were statistically different $(p<0.05$, Table 5). ICU patients had a higher ISS and NISS score, and a lower RTS and TRISS score for patients who were hospitalized in trauma services (Table 5).

According to the correlation analyses the hospitalization time in the ICU was statistically significant for NISS, RTS, and TRISS scores (Table 6), whereas the correlation coefficient was weak for all this trauma scores.

From 38 patients who were admitted in ICU, 20 patients were mechanically ventilated. The trauma scores were significantly different between the mechanically ventilated and nonmechanically groups $(p<0.05$, Table 7$)$. According to the $p$

Table 3. Trauma scores of in- and out-patients

\begin{tabular}{|c|c|c|c|}
\hline \multirow[t]{2}{*}{ Trauma scores } & \multirow{2}{*}{$\begin{array}{c}\begin{array}{c}\text { Inpatient trauma } \\
\text { score }(\mathrm{n}=378)\end{array} \\
\text { Mean } \pm S D\end{array}$} & \multirow{2}{*}{$\begin{array}{c}\begin{array}{c}\text { Outpatient trauma } \\
\text { score }(n=255)\end{array} \\
\text { Mean } \pm S D\end{array}$} & \multirow[t]{2}{*}{$\mathbf{p}$} \\
\hline & & & \\
\hline \multirow[t]{2}{*}{ Injury severity score } & $8.85 \pm 7.79$ & $1.82 \pm 2.46$ & $\mathrm{t}=16.38$ \\
\hline & & & $=0.001$ \\
\hline \multirow[t]{2}{*}{ New injury severity score } & $10.61 \pm 9.28$ & $2.10 \pm 3.04$ & $t=16.55$ \\
\hline & & & $=0.001$ \\
\hline \multirow[t]{2}{*}{ Revised trauma score } & $7.68 \pm 0.56$ & $7.80 \pm 0.49$ & $\mathrm{t}: 2.97$ \\
\hline & & & $=0.004$ \\
\hline \multirow[t]{2}{*}{ Trauma revised injury severity score } & $97.12 \pm 9.49$ & $99.34 \pm 0.66$ & $\mathrm{t}=4.5 \mathrm{I}$ \\
\hline & & & $=0.004$ \\
\hline
\end{tabular}

SD: Standard deviation.

Table 4. Correlation analyses between trauma scores and hospitalization time

\begin{tabular}{lcccc}
\hline Trauma scores & ISS & NISS & RTS & TRISS \\
\hline Hospitalization time & $r=0.36$ & $r=0.42$ & $r=-0.20$ & $r=-0.14$ \\
& $p=0.001$ & $p=0.001$ & $p=0.001$ & $p=0.001$ \\
\hline
\end{tabular}

ISS: Injury severity score; NISS: New injury severity score; RTS: Revised trauma score; TRISS: Trauma revised injury severity score. 
Table 5. Trauma scores according to the hospitalization ward

\begin{tabular}{|c|c|c|c|}
\hline \multirow[t]{2}{*}{ Scores } & \multirow{2}{*}{$\frac{\text { Intensive care unit }}{\text { Mean } \pm \text { SD }}$} & \multirow{2}{*}{$\frac{\text { Service patients }}{\text { Mean } \pm S D}$} & \multirow[t]{2}{*}{ Result } \\
\hline & & & \\
\hline \multirow[t]{2}{*}{ Injury severity score } & $17.50 \pm 10.54$ & $7.91 \pm 6.78$ & $t=5.48$ \\
\hline & & & $p=0.001$ \\
\hline \multirow[t]{2}{*}{ New injury severity score } & $20.00 \pm 11.02$ & $9.58 \pm 8.45$ & $t=5.64$ \\
\hline & & & $p=0.001$ \\
\hline \multirow[t]{2}{*}{ Revised trauma score } & $6.66 \pm 1.30$ & $7.79 \pm 0.21$ & $t=5.33$ \\
\hline & & & $p=0.001$ \\
\hline \multirow[t]{2}{*}{ Trauma revised injury severity score } & $87.75 \pm 17.73$ & $98.17 \pm 4.42$ & $t=3.58$ \\
\hline & & & $p=0.001$ \\
\hline
\end{tabular}

SD: Standard deviation.

Table 6. Correlation between hospitalization time in ICU and trauma scores

\begin{tabular}{lcccc}
\hline Scores & ISS & NISS & RTS & TRISS \\
\hline Hospitalization time in ICU & $r=0.19$ & $r=0.32$ & $r=-0.32$ & $r=-0.39$ \\
& $p=0.257$ & $p=0.048$ & $p=0.048$ & $p=0.017$ \\
\hline
\end{tabular}

ISS: Injury severity score; NISS: New injury severity score; RTS: Revised trauma score; TRISS: Trauma revised injury severity score; ICU: Intensive care unit.

Table 7. Trauma scores among mechanically ventilated and non-mechanically ventilated patients in the intensive care unit

\begin{tabular}{|c|c|c|c|}
\hline \multirow[t]{2}{*}{ Trauma scores } & $\begin{array}{l}\text { Mechanically } \\
\text { ventilated }\end{array}$ & $\begin{array}{c}\text { Non-mechanically } \\
\text { ventilated }\end{array}$ & Result \\
\hline & Mean $\pm S D$ & Mean \pm SD & \\
\hline Injury severity score & $22.20 \pm 11.67$ & $12.27 \pm 5.89$ & $p=0.013$ \\
\hline New injury severity score & $24.85 \pm 12.00$ & $|4.6| \pm 6.70$ & $p=0.009$ \\
\hline Revised trauma score & $6.12 \pm 1.36$ & $7.27 \pm 0.93$ & $\mathrm{p}=0.005$ \\
\hline Trauma revised injury severity score & $80.19 \pm 21.08$ & $96.16 \pm 6.76$ & $p=0.001$ \\
\hline
\end{tabular}

SD: Standard deviation.

Table 8. Mechanically ventilation time and trauma scores

\begin{tabular}{lcccc}
\hline Trauma scores & ISS & NISS & RTS & TRISS \\
\hline Mechanically ventilation time & $r=0.27$ & $r=0.38$ & $r=-0.17$ & $r=-0.56$ \\
& $p=0.243$ & $p=0.096$ & $p=0.467$ & $p=0.010$ \\
\hline
\end{tabular}

ISS: Injury severity score; NISS: New injury severity score; RTS: Revised trauma score; TRISS: Trauma revised injury severity score.

values we found that the physiological trauma scores (TRISS) can predict the mechanical ventilation need better than the anatomical trauma scores (RTS, NISS) $(p=0.001, p=0.005$, $p=0.013$, and $p=0.009$, respectively).
Except TRISS, none of the trauma scores had a significant $P$ value for determination the mechanically ventilation time. There was a strong negative relationship between TRISS and mechanically ventilation time (Table 8 ). 


\section{DISCUSSION}

In order to deliver effective, patient centered, efficient, equitable, and timely care to trauma patients by emergency medicine physicians they have to measure the quality of care they deliver with reliable and valid tools. Trauma scoring systems have been developed to estimate the probability of survival, facilitate pre-hospital triage, allow accurate comparison of different trauma populations, evaluate trauma care, compare trauma patient outcomes among hospitals, and organize and improve trauma systems. ${ }^{[1-13]}$

More than 50 scoring systems have been published for the classification of trauma patients in the emergency room and intensive care settings. ${ }^{[14-16]}$ The most frequently used trauma scores are AIS, RTS, TRISS, and ISS. These scores are general trauma scores. In our study, we compared the anatomical scoring systems (NISS, ISS), physiological (RTS), and combined scoring systems (TRISS) among adult trauma patients to find out the most effective one.

Eryilmaz et al. ${ }^{[17]}$ analyzed the patients who were falling from a height and compared the trauma scores (ISS, RTS, NISS, and TRISS). They found the TRISS was most sensitive and specific for predicting the mortality. In our study, we analyzed also the traffic accidents, blunt traumas, penetrating stab-gunshot wounds and we found that the entire trauma scores (ISS, NISS, RTS, and TRISS) were equally significant for the mortality prediction $(p<0.05$, Table 2$)$.

Güneytepe et al. ${ }^{[18]}$ compared the GCS, RTS, ISS, and TRISS among the elderly trauma patients and found TRISS as the most effective for mortality prediction. Whereas in our study, we analyzed all the individuals over 16 years and found that all of the trauma scores; ISS, NISS, RTS, and TRISS, were significant for the mortality prediction $(p<0.05$, Table 2$)$. In spite of the fact that the mean age was higher among patients who died, there wasn't any significant statistical correlation between age and survival rate $(p>0.05$, Table 3$)$. This could be due to the low mortality rate, only eight patients.

Aydin et al. ${ }^{[3]}$ compared the efficacy of ISS and NISS for predicting the mortality in patients with multiple trauma and searched the answer if ISS could take the place of NISS in TRISS model. At the end of the study, they didn't found any significant difference between ISS and NISS for predicting mortality and also NISS was not an alternative for ISS in TRISS model. In our study, we compared both anatomical, physiological and combined trauma scores (ISS, NISS, RTS, and TRISS) for the mortality prediction and all of them were equal to each other for the prediction of mortality $(p<0.05$, Table 2$)$.

Honarmand ${ }^{[19]}$ analyzed the effectivity of ISS and NISS among the trauma patients who were admitted to ICU. They found that NISS was better for determining "Need for intubation" and "mechanical ventilation." In our study, all scores (ISS,
NISS, RTS, and TRISS) were effective for determining the mechanically ventilation need $(p<0.05)$. When their significance was compared according to their $p$ values it was listed as TRISS, RTS, NISS, and ISS, respectively.

TRISS was the only trauma score in our study, which determined the mechanically ventilation time significantly. In spite of the fact that all trauma scores were equally significant for determining the need for ICU, the anatomic scoring systems were more effective. Except ISS, all of the trauma scores could predict the length of stay in ICU.

Fedakar et al. ${ }^{[20]}$ compared the ISS, NISS, GCS, RTS, and TRISS scores among patients with a life-threatening condition descripted according to Turkish criminal law. They found that ISS and NISS were the most appropriate trauma scores. In our study, we found that NISS and ISS could determine the need for ICU better. Whereas TRISS was more successful in determination the mechanically ventilation time and stay in ICU.

Lavoie et al. ${ }^{[21]}$ compared NISS with ISS among patients with moderate and severe head trauma for the ICU admission and length of hospital stay, and NISS was found to be better than ISS for the prediction. In our study, ICU need was predicted by all trauma scores significantly, but NISS was more successful. All scores were equally significant in determination hospitalization time.

Schluter et al. ${ }^{[22]}$ analyzed the predictivity of TRISS among the trauma patients to estimate the length of hospital stay. The result showed that TRISS was not sufficient and reliable to predict the length of hospital stay and useable for the followup. In our study, all trauma scores were statistically significant for the estimation of hospitalization time.

Like in our study, Eryilmaz et al. ${ }^{[23]}$ compared anatomic and physiological scores in terms of mortality and they did not found superiority to each other.

Bilgin et al. ${ }^{[2]}$ have analyzed trauma scores effectivitiy for writing effective forensic reports among trauma victims. Although all trauma scores were significant the ISS method was found to be more successful. According to our results anatomical scores (NISS and ISS) exhibited the need for ICU, and TRISS determinates the mechanical ventilation need and length of ICU treatment better.

Between the anatomical scoring systems NISS predictive power was relatively higher than ISS in our study in terms of morbidity (hospital and ICU admission requirements, length of stay in ICU, mechanical ventilation need). This can be while the serious injuries in the same region are preferred than a slight injury in a different body region for NISS calculation. NISS and ISS predictive power were equal to each other in terms of length of hospital stay. 
There was not a statistically significant relationship between mortality and age or injury mechanism. This could be due to the low mortality rate, eight patients. Furthermore, the mortality rate between genders could not be made while all of the patients who died were male.

All of the victims and the majority of trauma patients (76.1\%) are male. This could be while men live more active, travel more, most of the drivers are men, and they are present more in the trauma environments.

Osler et al.,., ${ }^{[25]}$ summarizes the algorithm used for estimation of prognosis as; anatomical injury + physiological injury + patients reserve. Accordingly, it is difficult to predict the prognosis only with the anatomical and physiological injury scores. In addition, age, existing chronic diseases, and possible genetic predispositions varies patient's survival rate in trauma patients. In spite of the fact that this could be a better formulation for estimation the prognosis, it doesn't differs the results of our trauma scores effectivity.

Age and trauma mechanism factors are considered in TRISS, opposed to other score calculations. This enables both anatomical and physiological trauma determination which can make TRISS superior to other trauma scores. As a result of our research, TRISS has established ICU length of stay and mechanical ventilation need better.

It is accepted that ISS results are close to TRISS, and that's why ISS is used commonly for TRISS in practice. This is not supported by our study.

\section{Acknowledgments}

At the end of our study, we found that all of the trauma scores were equal significant for predicting the hospitalization ward and mortality, mechanically ventilation and hospitalization need. Only in predicting the ICU hospitalization time TRISS was better. To determine the superiorities of the trauma scores better, multicentric studies with more patients can be made. Furthermore, new trauma scores with different parameters can be designed.

Conflict of interest: None declared.

\section{REFERENCES}

1. Özgüç H, Kaya E, Korun N. Factors Affecting Outcome In The Resuscitation of Trauma. Ulus Travma Acil Cerrahi Derg 1995;1:51-8.

2. Dur A, Cander B, Koçak S, Girişgin S, Gül M, Koyuncu F. Multiple trauma patients and trauma scoring systems in emergency-intensive care unit. JAEM 2009;8:24-27.

3. Aydin SA, Bulut M, Ozgüç H, Ercan I, Türkmen N, Eren B, et al. Should the New Injury Severity Score replace the Injury Severity Score in the Trauma and Injury Severity Score? Ulus Travma Acil Cerrahi Derg 2008; $14: 308-12$.

4. Baker SP, O'Neill B, Haddon W Jr, Long WB. The injury severity score: a method for describing patients with multiple injuries and evaluating emergency care. J Trauma 1974;14:187-96. CrossRef

5. Boyd CR, Tolson MA, Copes WS. Evaluating trauma care: the TRISS method. Trauma Score and the Injury Severity Score. J Trauma 1987;27:370-8. CrossRef

6. Hurst James M. Trauma: an overview. In: Rippe JM, Irwin RS. editors. Intensive care medicine. 5 th ed. Boston: Little, Brown and Company; 1991. p.1455-6.

7. Roberton C, Redmond AD. The management of major trauma. 6th ed. Oxford, USA: Oxford University Press; 1994.

8. Yağmur Y, Güloğlu C, Uğur M, Akkuş Z, Elik Y. Evaluatıon Of Patients With Multiple Injuries: Comparison Of Injury Severity Score And Revised Trauma Score. Ulus Travma Acil Cerrahi Derg 1997;3:73-7.

9. Gennarelli TA, Champion HR, Copes WS, Sacco WJ. Comparison of mortality, morbidity, and severity of 59,713 head injured patients with 114,447 patients with extracranial injuries. J Trauma 1994;37:962-8.

10. İhtiyar E, Ünlüoğlu I, Şahin A, Caga T, Karahüseyinoğlu E. The Evaluation Of Multi - Trauma Patients with GCS, TS, AIS At Osmangazi University Faculty Of Medicine Emergency Service: Prospective Evaluation Of 734 Patients. Ulus Travma Acil Cerrahi Derg 1998;4:176-9.

11. Veenema KR, Rodewald LE. Stabilization of rural multiple-trauma patients at level III emergency departments before transfer to a level I regional trauma center. Ann Emerg Med 1995;25:175-81. CrossRef

12. Fallon WF Jr, Barnoski AL, Mancuso CL, Tinnell CA, Malangoni MA. Benchmarking the quality-monitoring process: a comparison of outcomes analysis by trauma and injury severity score (TRISS) methodology with the peer-review process. J Trauma 1997;42:810-7. CrossRef

13. Moini M, Rezaishiraz H, Zafarghandi MR. Characteristics and outcome of injured patients treated in urban trauma centers in Iran. J Trauma 2000;48:503-7. CrossRef

14. Esme H, Solak O, Yurumez Y, Yavuz Y, Terzi Y, Sezer M, et al. The prognostic importance of trauma scoring systems for blunt thoracic trauma. Thorac Cardiovasc Surg 2007;55:190-5. CrossRef

15. Champion HR, Sacco WJ, Copes WS, Gann DS, Gennarelli TA, Flanagan ME. A revision of the Trauma Score. J Trauma 1989;29:623-9.

16. Bouillon B, Lefering R, Vorweg M, Tiling T, Neugebauer E, Troidl H. Trauma score systems: Cologne Validation Study.J Trauma 1997;42:6528. CrossRef

17. Eryılmaz M, Durusu M, Menteş Ö, Özer T, Kılıç S, Ersoy G, et al. Comparison of trauma scores for adults who fell from height as survival predictivity. Turk J Med Sci 2009;39:247-52.

18. Güneytepe Üİ, Aydın ŞA, Gökgöz Ş, Özgüç H, Ocakoğlu G, Aktaş H. The factors influencing the mortality in elderly trauma patients and scoring systems. Uludag Medical Journal 2008;34:15-9.

19. Honarmand A, Safavi M. The new Injury Severity Score: a more accurate predictor of need ventilator and time ventilated in trauma patients than the Injury Severity Score. Ulus Travma Acil Cerrahi Derg 2008;14:1107.

20. Fedakar R, Aydiner AH, Ercan I. A comparison of "life threatening injury" concept in the Turkish Penal Code and trauma scoring systems. Ulus Travma Acil Cerrahi Derg 2007;13:192-8.

21. Lavoie A, Moore L, LeSage N, Liberman M, Sampalis JS. The Injury Severity Score or the New Injury Severity Score for predicting intensive care unit admission and hospital length of stay? Injury 2005;36:477-83. CrossRef

22. Schluter PJ, Cameron CM, Davey TM, Civil I, Orchard J, Dansey R, et al. Using Trauma Injury Severity Score (TRISS) variables to predict length of hospital stay following trauma in New Zealand. N Z Med J 2009;122:65-78. 
23. Eryilmaz M, Durusu M, Cantürk G, Menteș MO, Ozer MT, Cevik E, et al. Role of anatomic and physiologic trauma scoring systems in forensic cases. Ulus Travma Acil Cerrahi Derg 2009;15:285-92.

24. Bilgin NG, Mert E, Camdeviren $\mathrm{H}$. The usefulness of trauma scores in determining the life threatening condition of trauma victims for writing medical-legal reports. Emerg Med J 2005;22:783-7. CrossRef

25. Osler T, Rutledge R, Deis J, Bedrick E. ICISS: an international classification of disease- 9 based injury severity score. J Trauma 1996;41:380-8.

\title{
KLINIKK ÇALIŞMA - ÖZET
}

\section{Travma hastalarında mortalite ve morbidite öngörüsünde travma skorlamalarının karşılaştırılması Dr. Reyhan Orhon, ${ }^{1}$ Dr. Şevki Hakan Eren, ${ }^{2}$ Dr. Şule Karadayı, ${ }^{2}$ Dr. İlhan Korkmaz, ${ }^{2}$
Dr. Abuzer Coşkun, ${ }^{2}$ Dr. Mehmet Eren, ${ }^{3}$ Dr. Nurkay Katrancıoğlu ${ }^{4}$}

\author{
${ }^{1}$ Gaziantep Devlet Hastanesi, Acil Tıp Kliniği, Gaziantep; \\ ${ }^{2}$ Cumhuriyet Üniversitesi Hastanesi, Acil Servis, Sivas; \\ ${ }^{3}$ Ankara Yenimahalle Devlet Hastanesi, Ortopedi ve Travmatoloji Kliniği, Ankara; \\ ${ }^{4}$ Cumhuriyet Üniversitesi Hastanesi, Kalp Damar Cerahisi Servisi, Sivas
}

AMAÇ: Bu çalışmada travmalı olgularda anatomik ve fizyolojik skorlama sistemleri (TRISS, RTS, ISS, NISS) birbiriyle karşılaştırılarak, mortalite ve morbiditeyi hangi travma skorunun en doğru ve güvenilir bir şekilde tahmin ettiğinin araştırılması amaçlandı.

GEREÇ VE YÖNTEM: Çalışmamız, üniversite hastanesi acil servisi'ne sekiz aylık dönemde travma nedeniyle başvuran 633 hastanın kesitsel olarak incelenmesi yöntemiyle yapıldı. Çalışmaya 16 yaş ve üzerindeki künt ve penetran travmalı (trafik kazası, ateşli silah yaralanması, delici-kesici alet yaralanması gibi) hastalar alındı.

BULGULAR: Hastaların geliş anındaki travma skorları (ISS, NISS, RTS, TRISS) hesaplandı. Mortalite tahmini için ortalama travma skoru hesaplandı ve $p$ değeri tümü için eşit bulundu $(p=0.001)$. Travma skorları yoğun bakım ünitesinde yatış süresi için analiz edildiğinde, NISS, RTS ve TRISS skorlama değerleri anlamlı ( $p=0.048, p=0.048$ and $p=0.017$ sırasıyla), ISS skorlaması anlamlı değildi $(p=0.257)$. Sadece TRISS skorlama sisteminin yoğun bakım ünitesi hastalarında mekanik ventilasyonda kalma süresini tahmin etmede iyi bir belirleyici olduğu bulundu ( $\mathrm{p}=0.0 \mathrm{I}$ ).

TARTIŞMA: Sonuç olarak hastaneye yatış gereksinimini ve yoğun bakımda yatış gereksinimini anatomik skorlama sistemleri olan NISS ve ISS'nin; yoğun bakımda yatış süresi ve mekanik ventilatörle ilgili süreci ise anatomofizyolojik skor olan TRISS'nin daha iyi öngördüğünü tespit ettik. Anahtar sözcükler: Morbidite; mortalite; travma; travma skoru.

Ulus Travma Acil Cerrahi Derg 20।4;20(4):258-264 doi: 10.5505/tjtes.20।4.22725 